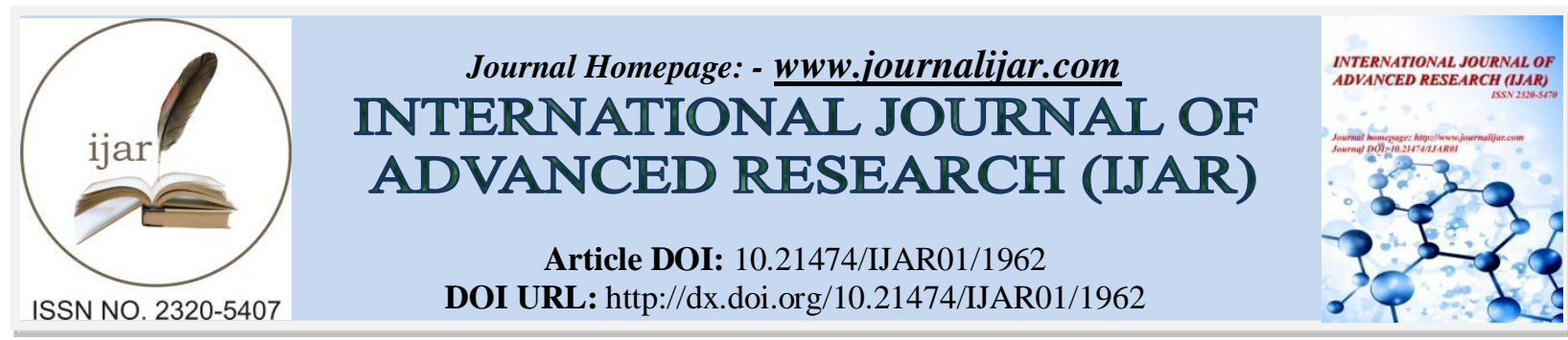

RESEARCH ARTICLE

\title{
LEVEL OF AWARENESS ON DIABETES, ITS COMPLICATIONS AND MEDICATIONS AMONG DIABETIC PATIENTS ATTENDING KING FAISAL HOSPITAL INTAIF CITY: A CROSS-SECTIONAL STUDY.
}

\author{
Maram Hassan Al Sufyani ${ }^{1}$, Daniyah Hassan Saleh ${ }^{1}$ and Elham Hamed Alrubai ${ }^{2}$. \\ 1. Medical Intern, Collage of medicine, Taif University, Saudi Arabia. \\ 2. Internal Medicine Specialist.
}

\section{Manuscript Info}

\section{Manuscript History}

Received: 12 August 2016

Final Accepted: 22 September 2016

Published: October 2016

Key words:-

Awareness; Knowledge; Diabetes;

Complications; Risk factors

\section{Abstract}

Background:- Several challenges in diabetes management need to be tackled in Saudi Arabia, including the growing prevalence, particularly among children and young adults, micro-and macrovascular complications, lifestyle changes, late diagnosis, poor awareness and high treatment costs.

Objectives: To assess the level of awareness on diabetes, its complications and medications among diabetic patients in Taif City.

Subjects and methods:- This is a cross-sectional study carried out among a convenient sample of 100 diabetic patients of both genders and aged over 30 years attended diabetic clinics, King Faisal Hospital in Taif City. Data were collected using a valid questionnaire contained question about socio-demographic characteristics of the patients, questions on patient's diabetic characteristics and 15 questions inquing about patients` knowledge regarding diabetes.In addition last level of HbA1c has been obtained from patients`medical files.

Results:- One hundred patients with type 2 diabetes were recruited for the study. Forty percent of them were in the age group of $\geq 60$ years. Half of them were females. Insufficient knowledge regarding diabetes was reported among $61 \%$ of the diabetics. However, among those treated with insulin, $93.1 \%$ stored it in the fridge and $41.4 \%$ reported changeable sites for insulin injection as shown in figure 2. Majority of diabetic patients were aware about diabetes risk factors $(95 \%)$. On the other hand, only $9 \%$ of patients were aware of the diabetic complications and almost one third of them were aware of the normal level of blood glucose (31\%), normal level of blood glucose during fasting $(35 \%)$ and two hours after meal $(38 \%)$. University graduated patients were more significantly had higher sufficient knowledge of diabetes than illiterates $(62.9 \%$ versus $20.6 \%), p=0.013$. Working patients were more knowledgeable than not working patients $(61.9 \%$ versus $24.4 \%$ ), $\mathrm{p}=0.011$. Duration of diabetes was a significant predictor for having sufficient awareness and knowledge about the disease as $47.9 \%$ of those whose duration of diabetes exceeded 10 years compared to none of those with less than two years of diabetes had sufficient knowledge about the disease, $p=0.047$. Controlled diabetic patients (HBA1c\% 6.5-7) had higher sufficient knowledge 
about diabetes compared to those whose HBA1c exceeded $10 \%$ (71.4\% versus $40 \%)$. The difference was statistically significant, $\mathrm{p}=0.041$.

Conclusion:- Diabetic patients in Taifhave enough knowledge of the risk factors and symptoms of diabetes. However, they are not very well aware of thediabetes associated secondary complications.

Copy Right, IJAR, 2016,. All rights reserved.

\section{Introduction:-}

According to the American Diabetic Association (ADA), diabetes mellitus (DM) is a group of metabolic diseases characterized by hyperglycemia resulting from defects in insulin secretion, insulin action, or both. It is a worldwide health problem. ${ }^{1}$ Saudi Arabia has the second highest rate of diabetes in the Middle East and is seventh highest in the world, according to the World Health Organization (WHO). ${ }^{2}$

DM is considered a major public health problem in Saudi Arabia as the prevalence was $34.1 \%$ in males and 27.6\% in females according to Alqurashiet al (2011). ${ }^{3}$

Several challenges in diabetes management need to be tackled in Saudi Arabia, including the growing prevalence, particularly among children and young adults, micro-and macrovascular complications, lifestyle changes, late diagnosis, poor awareness and high treatment costs. ${ }^{4}$

DiabetesMellitus (DM) has many complications that divided into micro-vascular such as diabetic retinopathy, nephropathy and neuropathy and macro-vascular complications such as coronary artery disease, peripheral vascular disease, stroke and diabetic foot. ${ }^{5}$

Although the importance of educational programs in the prevention and control of DM is well recognized, ${ }^{6}$ there are concerns whether these programs are achieving the desired goal of increasing awareness of DM in developing countries. Indeed, several studies have consistently shown that awareness of the DM in the general population seems to be low. ${ }^{7-14}$

With proper education, awareness, early detection and management, many complications and co-morbidities can be reduced in diabetic population. ${ }^{15}$

Although diabetes is a silent disease that affects patients` life style there is lack of knowledge about diabetes among diabetic populations. Therefore, this study was carried out to assess the level of awareness on diabetes, its complications and medications among diabetic patients in Taif City.

\section{Subjects and Methods:-}

This is a cross-sectional study carried out among a convenient sample of 100 diabetic patients of both genders and aged over 30 years attended. It is a tertiary care hospital. The study was carried out throughout one month (August, 2016).

Sample size was estimated using Epi-info Version 7 software StatCalc key. Thesize of the adult population from which the sample would be selected was the adult populationof Taif city (approximately 250000) and the expected frequency of diabetes was $27.6 \%{ }^{3}$ Thisgave a sample size of 98 patients at $99.9 \%$ confidence interval.

Data were collected using a valid questionnaire adopted from that uses in a study carried out by Prasad. ${ }^{16}$ It contained question about socio-demographic characteristicsof the patients such as gender, age, marital status, residence, level of education and job status. Also, it included questions on patient's diabetic characteristicssuch as duration of diabetes, family history, family support, diabetic complications and source ofinformation on diabetes. In addition last level of HbAlc has been obtained from patients` medical files. The participants' verbal consents were obtained prior to participation. 
Data entry and analysis were performed using SPSS version 22. Frequency and percentage were applied for data description whereas chi-square test was used for analysis of data and p-value less than 0.05 was used as a cut-off level for statistical significance.

\section{Results:-}

One hundred patients with type 2 diabetes were recruited for the study. Table 1 presents their socio-demographic characteristics. Forty percent of them were in the age group $\geq 60$ years. Half of them were females. Majority were married and resided urban areas (85\%). Almost one-third of them (34\%) were illiterate and $21 \%$ were university graduated. Less than half of the participants (45\%) were not working whereas $21 \%$ were workers.

Table 1:- Socio-demographic characteristics of the participants.

\begin{tabular}{|l|l|l|}
\hline & Frequency & Percentage \\
\hline Age & & \\
$30-39$ & 7 & 7.0 \\
$40-49$ & 25 & 25.0 \\
$50-59$ & 28 & 28.0 \\
$\geq 60$ & 40 & 40.0 \\
\hline Gender & 50 & \\
Male & 50 & 50.0 \\
Female & & 50.0 \\
\hline Marital status & 7 & \\
Single & 85 & 7.0 \\
Married & 8 & 85.0 \\
Others & & 8.0 \\
\hline Residence & 85 & \\
Urban & 15 & 85.0 \\
Rural & & 15.0 \\
\hline Educational level & 34 & \\
Illiterate & 30 & 34.0 \\
Primary & 15 & 30.0 \\
Intermediate/high & 21 & 15.0 \\
University & & 21.0 \\
\hline Job status & 21 & \\
Working & 45 & 21.0 \\
Not working & 34 & 45.0 \\
Retired & & 34.0 \\
\hline
\end{tabular}

As illustrated in table 2, 48\% of patients had diabetes since over 10 years. Family history of diabetes was reported among $66 \%$ of them. Family support in management of diabetes was present in $65 \%$ of patients. Slightly less than half of them (47\%) reported diabetic complications, including 19\% foot infection. Their source of information regarding diabetes was mainly from physicians or pharmacists $(60 \%)$. HbA1c\% exceeded 10 among $10 \%$ of the participants.

Table 2:- Diabetes-related characteristics of the participants.

\begin{tabular}{|l|l|l|}
\hline & Frequency & Percentage \\
\hline Duration of diabetes (years) & & \\
$<2$ & 6 & 6.0 \\
$2-5$ & 27 & 27.0 \\
$6-10$ & 19 & 19.0 \\
$>10$ & 48 & 48.0 \\
\hline Family history of diabetes & & \\
Yes & 66 & 66.0 \\
No & 34 & 34.0 \\
\hline Family support & 65 & 65.0 \\
Yes & 35 & 35.0 \\
No & & \\
\hline Diabetic complications & & \\
\hline
\end{tabular}




\begin{tabular}{|l|l|l|}
\hline Yes & 47 & 47.0 \\
No & 53 & 53.0 \\
\hline Foot infection & & \\
Yes & 19 & 19.0 \\
No & 81 & 81.0 \\
\hline Source of information about DM & & \\
Friends/family members & 17 & 17.0 \\
Physician/pharmacist & 60 & 60.0 \\
Social media/books & 14 & 14.0 \\
Others & 9 & 9.0 \\
\hline HbA1c (\%) & & \\
$6.5-7$ & 7 & 7.0 \\
$7.1-10$ & 19 & 19.0 \\
$>10$ & 10 & 10.0 \\
Don't know & 64 & 64.0 \\
\hline
\end{tabular}

As demonstrated in figure 1, insufficient knowledge regarding diabetes was reported among $61 \%$ of the diabetics. However, among those treated with insulin, $93.1 \%$ stored it in the fridge and $41.4 \%$ reported changeable sites for insulin injection as shown in figure 2 .

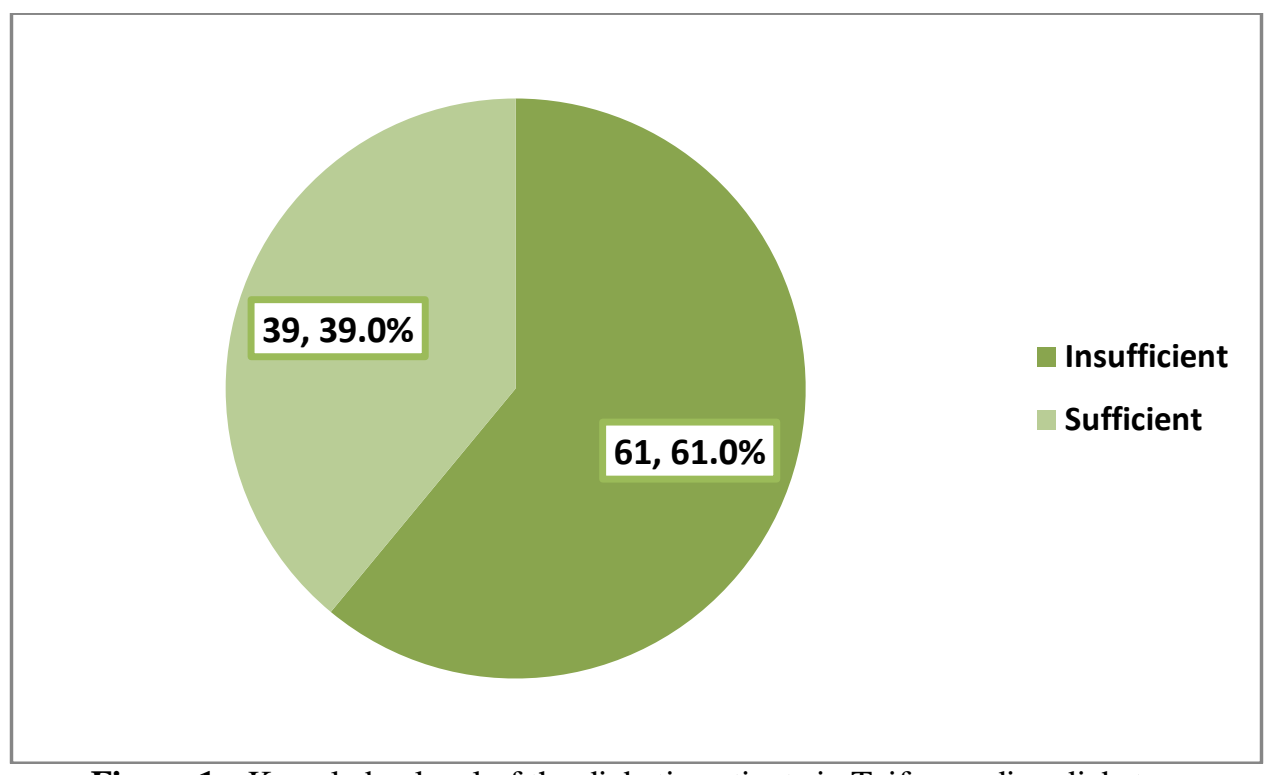

Figure 1:- Knowledge level of the diabetic patients in Taif regarding diabetes. 


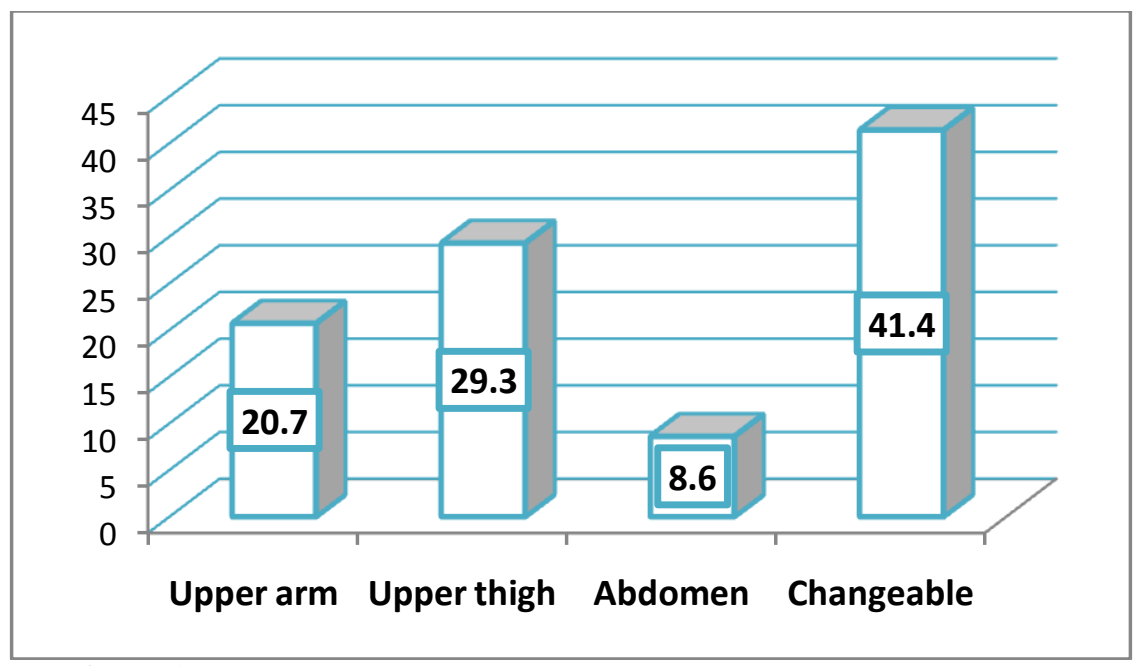

Figure 2:- Site of insulin injection among insulin-treated patients $(\mathrm{n}=58)$

Table 3 shows that majority of diabetic patients were aware about diabetes risk factors (95\%), the importance of extra-care during cutting toenails (92\%), regular eye checkup (91\%) and diabetic patients heals more slowly (81\%). On the other hand, only $9 \%$ of patients were aware of the diabetic complications and almost one third of them were aware of the normal level of blood glucose (31\%), normal level of blood glucose during fasting (35\%) and two hours after meal $(38 \%)$.

Table 3:- Responses of the participants to knowledge questions.

\begin{tabular}{|c|c|c|}
\hline & \multicolumn{2}{|c|}{ Right answers } \\
\hline & $\mathbf{N}$ & $\%$ \\
\hline $\begin{array}{l}\text { What is meant by diabetes Mellitus? } \\
\text { It means having too much sugar in the blood because of lack of insulin }\end{array}$ & 44 & 44.0 \\
\hline $\begin{array}{l}\text { Which of the following is the commonest type of diabetes found in Taif } \\
\text { Type } 2\end{array}$ & 70 & 70.0 \\
\hline $\begin{array}{l}\text { What are the factors that increase a chance of getting type } 2 \text { diabetes } \\
\text { Family history, high levels of fats in the body, overweight and }>40 \text { years of age }\end{array}$ & 95 & 95.0 \\
\hline $\begin{array}{l}\text { Diabetes is a condition which can be: } \\
\text { Controlled }\end{array}$ & 78 & 78.0 \\
\hline $\begin{array}{l}\text { What are the commonest symptoms of diabetes? } \\
\text { Feeling very thirsty and going to the toilet often }\end{array}$ & 77 & 77.0 \\
\hline $\begin{array}{l}\text { What is the normal blood sugar level? } \\
75-100 \mathrm{mg} / \mathrm{dL}\end{array}$ & 31 & 31.0 \\
\hline $\begin{array}{l}\text { What is the normal blood sugar level for diabetic patients when fasting? } \\
80-130 \mathrm{mg} / \mathrm{dL}\end{array}$ & 35 & 35.0 \\
\hline $\begin{array}{l}\text { What is the normal blood sugar level for diabetic patients taken two hours after eating food? } \\
<180 \mathrm{mg} / \mathrm{dL}\end{array}$ & 38 & 38.0 \\
\hline $\begin{array}{l}\text { When should you take your diabetes medication in regards to food? } \\
\text { Before food }\end{array}$ & 72 & 72.0 \\
\hline $\begin{array}{l}\text { When the blood sugar level remains high for a long period of time certain parts of the body get } \\
\text { damaged. Which of the following occur due to diabetes not controlled well? } \\
\text { Eyes problem, kidney damage, heart disease, stroke, and feet problems }\end{array}$ & 9 & 9.0 \\
\hline $\begin{array}{l}\text { Numbness and tingling may be symptoms of } \\
\text { nerve disease }\end{array}$ & 43 & 43.0 \\
\hline $\begin{array}{l}\text { What are some of the signs of low blood sugar levels? } \\
\text { Sweating, hunger, headache, confusion, rapid heartbeat, weakness and feeling faint }\end{array}$ & 79 & 79.0 \\
\hline $\begin{array}{l}\text { Should diabetic patients have regular eye check up? } \\
\text { Yes }\end{array}$ & 91 & 91.0 \\
\hline $\begin{array}{l}\text { Diabetic patients should take extra care when cutting their toenails: } \\
\text { Yes }\end{array}$ & 92 & 92.0 \\
\hline $\begin{array}{l}\text { Cuts in diabetic patients heal more slowly } \\
\text { Yes }\end{array}$ & 81 & 81.0 \\
\hline
\end{tabular}


Table 4 shows factors associated with awareness and knowledge regarding diabetes. University graduated patients were more significantly had higher sufficient knowledge of diabetes than illiterates $(62.9 \%$ versus $20.6 \%)$, $\mathrm{p}=0.013$. Working patients were more knowledgeable than not working patients $(61.9 \%$ versus $24.4 \%), \mathrm{p}=0.011$. Duration of diabetes was a significant predictor for having sufficient awareness and knowledge about the disease as $47.9 \%$ of those whose duration of diabetes exceeded 10 years compared to none of those with less than two years of diabetes had sufficient knowledge about the disease, $\mathrm{p}=0.047$. Controlled diabetic patients (HBA1c\% 6.5-7) had higher sufficient knowledge about diabetes compared to those whose HBA1c exceeded $10 \%$ (71.4\% versus $40 \%)$. The difference was statistically significant, $\mathrm{p}=0.041$.

Table 4:- Factors associated with awareness and knowledge of diabetes among diabetic patients, Taif.

\begin{tabular}{|c|c|c|c|}
\hline & \multicolumn{2}{|c|}{ DM knowledge } & \multirow[t]{2}{*}{ p-value } \\
\hline & $\begin{array}{c}\text { Insufficient } \\
(\mathrm{n}=61)\end{array}$ & $\begin{array}{c}\text { Sufficient } \\
(n=39)\end{array}$ & \\
\hline $\begin{array}{l}\text { Age (years) } \\
30-39(\mathrm{n}=7) \\
40-49(\mathrm{n}=25) \\
50-59(\mathrm{n}=28) \\
\geq 60(\mathrm{n}=40\end{array}$ & $\begin{array}{l}4(57.1) \\
14(56.0) \\
16(57.1) \\
27(67.5)\end{array}$ & $\begin{array}{l}3(42.9) \\
11(44.0) \\
12(42.9) \\
13(32.5)\end{array}$ & 0.755 \\
\hline $\begin{array}{l}\text { Gender } \\
\text { Male }(\mathrm{n}=50) \\
\text { Female }(\mathrm{n}=50)\end{array}$ & $\begin{array}{l}32(64.0) \\
29(58.0)\end{array}$ & $\begin{array}{l}18(36.0) \\
21(42.0)\end{array}$ & 0.539 \\
\hline $\begin{array}{l}\text { Marital status } \\
\text { Single }(n=7) \\
\text { Married }(n=85) \\
\text { Others }(n=8) \\
\end{array}$ & $\begin{array}{c}4(57.1) \\
51(60.0) \\
6(75.0)\end{array}$ & $\begin{array}{c}3(42.9) \\
34(40.0) \\
2(25.0) \\
\end{array}$ & 0.691 \\
\hline $\begin{array}{l}\text { Residence } \\
\text { Urban }(n=85) \\
\text { Rural }(n=15)\end{array}$ & $\begin{array}{l}51(60.0) \\
10(66.7)\end{array}$ & $\begin{array}{c}34(40.0) \\
5(33.3)\end{array}$ & 0.626 \\
\hline $\begin{array}{l}\text { Educational level } \\
\text { Illiterate }(n=34) \\
\text { Primary }(n=30) \\
\text { Intermediate/high }(n=15) \\
\text { University }(n=21) \\
\end{array}$ & $\begin{array}{l}27(79.4) \\
19(63.3) \\
7(46.7) \\
8(38.1) \\
\end{array}$ & $\begin{array}{c}7(20.6) \\
11(36.7) \\
8(53.3) \\
13(61.9) \\
\end{array}$ & 0.013 \\
\hline $\begin{array}{l}\text { Job status } \\
\text { Working }(n=21) \\
\text { Not working }(n=45) \\
\text { Retired }(n=34)\end{array}$ & $\begin{array}{c}8(38.1) \\
34(75.6) \\
19(55.9)\end{array}$ & $\begin{array}{l}13(61.9) \\
11(24.4) \\
15(44.1)\end{array}$ & 0.011 \\
\hline $\begin{array}{l}\text { Duration of diabetes (years) } \\
<2(n=6) \\
2-5(n=27) \\
6-10(n=19) \\
>10(n=48)\end{array}$ & $\begin{array}{l}6(100) \\
20(74.1) \\
10(52.6) \\
25(52.1) \\
\end{array}$ & $\begin{array}{c}0(0.0) \\
7(25.9) \\
9(47.4) \\
23(47.9) \\
\end{array}$ & 0.047 \\
\hline $\begin{array}{l}\text { Family history of diabetes } \\
\text { Yes }(n=66) \\
\text { No }(n=34)\end{array}$ & $\begin{array}{l}39(59.1) \\
22(64.7)\end{array}$ & $\begin{array}{l}27(40.9) \\
12(35.3)\end{array}$ & 0.586 \\
\hline $\begin{array}{l}\text { Family support } \\
\text { Yes }(n=65) \\
\text { No }(n=35)\end{array}$ & $\begin{array}{l}36(55.4) \\
25(71.4)\end{array}$ & $\begin{array}{l}29(44.6) \\
10(28.6)\end{array}$ & 0.117 \\
\hline $\begin{array}{l}\text { Diabetic complications } \\
\text { Yes }(n=47) \\
\text { No }(n=53)\end{array}$ & $\begin{array}{l}27(57.4) \\
34(64.2)\end{array}$ & $\begin{array}{l}20(42.6) \\
19(35.8)\end{array}$ & 0.493 \\
\hline $\begin{array}{l}\text { Foot infection } \\
\text { Yes }(n=19) \\
\text { No }(n=81) \\
\end{array}$ & $\begin{array}{c}8(42.1) \\
53(65.4)\end{array}$ & $\begin{array}{l}11(57.9) \\
28(34.6)\end{array}$ & 0.061 \\
\hline $\begin{array}{l}\text { Source of information about DM } \\
\text { Friends/family members }(n=17) \\
\text { Physician/pharmacist }(n=60) \\
\text { Social media/books }(n=14) \\
\text { Others }(n=9)\end{array}$ & $\begin{array}{l}10(58.8) \\
39(65.0) \\
6(42.9) \\
6(66.7)\end{array}$ & $\begin{array}{c}7(41.2) \\
21(35.0) \\
8(57.1) \\
3(33.3)\end{array}$ & 0.476 \\
\hline $\begin{array}{l}\text { HbA1c }(\%) \\
6.5-7(\mathrm{n}=7) \\
7.1-10(\mathrm{n}=19) \\
>10(\mathrm{n}=10) \\
\text { Don`t know }(\mathrm{n}=64)\end{array}$ & $\begin{array}{l}2(28.6) \\
8(42.1) \\
6(60.0) \\
45(70.3)\end{array}$ & $\begin{array}{c}5(71.4) \\
11(57.9) \\
4(40.0) \\
19(29.7)\end{array}$ & 0.041 \\
\hline
\end{tabular}




\section{Discussion:-}

The present study demonstrates that the overall diabetes knowledge among diabetic patients attended diabeticclinics;King Faisal Hospital in Taif City was inadequate as insufficient knowledge was reported among $61 \%$ of them.Bivariateanalysis revealed that, the higher educated patients had more sufficient knowledge than low educated patients. Thedata is consistent with previous studies from other partsof the world that showed the association between level of education and the increase in DM knowledge. ${ }^{(17-20)}$ In addition, the same finding has been reported in Saudi Arabia by Mohieldein, et al (2011). ${ }^{(21)}$

Some important areas of deficiency and misconceptionhave been identified for targeted health education effort in the present study such as the normal level of random and fasting blood sugar, normal post-prandial blood sugar and the proper time of taking diabetic therapy as majority of patients reported after sometimes of a meal.

In fact, DM is a chronic disease that requires ongoingmonitoring and treatment. ${ }^{(22)}$ Recently,Sabra et al. (2010) ${ }^{(23)}$ have reported in their cross-sectionalstudy conducted in Eastern Saudi Arabia among primaryhealth care centers attendees, that a quarter of theattendees (of whom $92 \%$ were Saudi) held themisconception that, treatment should be stopped ifdiabetes is well controlled for months. This misconceptionfor the majority may lead to an increased number ofdiabetics over the next years in the region, especially dueto increasing urbanization and general changes inbehaviour patterns and sedentary lifestyles. Contrast to that, in the present study, fortunately the majority of the participants believed that DM is not a curable disease but con be well controlled.

Saudi Arabia has experienced a rapid increase in wealth over arelatively short period of time, as a consequence of thefinancial gains rendered by the oil industry, paralleledwith swift industrialization and urbanization. ${ }^{(24,25)}$ This was accompanied with increase in the prevalence of DM. ${ }^{(26)}$ In the current study, fortunately, the majority of them recognized the risk factors for diabetes.

Among important findings of the present stud is finding that controlled patients were more knowledgeable and aware of the disease. This confirms the usual impact of awareness and knowledge of the diabetes on its control.

Majority of the participants could recognize the common risk factors for diabetes in the present study. This result contradicts that done by Aljoudi and Taha $(2009)^{(27)}$ who reported lack of knowledge of risk factors of DM in Eastern Saudi Arabia and in accordance to that reported by Mohieldeinet al, 2011 who reported that the knowledge of risk factors and symptoms of DMwas 63.4 and $80.8 \%$ respectively. ${ }^{(13)}$ Moreover, the good knowledge on thesymptoms of DM in this study, may imply the highprevalence of DM among Saudi population in. Unlike good knowledge on symptoms of DM, this study revealed low level ofawareness about the complications of DM. This lack of knowledge regardingcomplication of DM, may lead toexpect the limited knowledge about the fact that diabeticpatients may develop a silent serious outcomes. ${ }^{(28)}$

Awareness about complications of DM was found to belower also in Pakistan. Ulvi et al (29) reported that,approximately $88 \%$ of respondents in that study wereunable to say that, they had any idea as to what thecomplications of diabetes might be. Moreover, thisdemand for required efforts to educate general populationabout complications of DM was reported from India and Malaysia. ${ }^{(30,31)}$

Regarding the sources of information about DM amongthe participants, the healthcare professionals representedthe highest percent (60\%). Lower percentage(17.8\%) was reported by Sabra et al. (2010) ${ }^{(23)}$ from EasternSaudi Arabia. In support of that view, Al-Rubeaan $(2003)^{(32)}$ claimed that "there is a serious gap in the provision ofbasic educational services to the majority of people withdiabetes in the region". Primary health care (PHC) is thefirst level of professional contact in the community andforms the corner-stone strategy for the attainment of levelof health that will permit socially and economicallyproductive life. ${ }^{(33)}$

Conclusively, diabetic patients in Taif have enough knowledge of the risk factors and symptoms of diabetes. However, they are not very well aware of thediabetes associated secondary complications. Therefore, we recommended educating diabetic patients about DM within the PHC, particularly, complications. This may be achieved by using audio-visual aids, as well as posters showing patients with diabetes complications and their consequences such as lower limb amputation, blindness, and renal dialysis. 
The results of this studycould contribute positively and meaningfully to thedesign of future educational programme and materials.An improved educational programme that tackles theareas of weaknesses or misconceptions can potentiallyincrease the level of public awareness of diabetes.

\section{Acknowledgements:-}

The authors would like to thank Asma dhafer Alamri, Zohoor Muteb Almalki, Wala Nawaf Alharthi and Hissa Ayedh Albogami for their great effort in data collection.

\section{References:-}

1. American Diabetes Association. Diagnosis and Classification of Diabetes Mellitus. Diabetes Care. 2009 Jan; 32(Suppl 1): S62-S67.

2. Wild S, Roglic G, Green A, Sicree R, King H. Global Prevalence of Diabetes: Estimates for the year 2000 and projections for 2030. Diabetes Care 2004;27:1047-1053

3. Alqurashi K, Aljabri K, Bokhari S. Prevalence of diabetes mellitus in a Saudi community. Annals of Saudi medicine. 2011;31(1):19-23

4. Robert AA, Al Dawish MA, Braham R, Musallam MA, Al Hayek AA, Al Kahtany NH. Type 2 Diabetes Mellitus in Saudi Arabia: Major Challenges and Possible Solutions. Curr Diabetes Rev. 2016 Jan 26.

5. Ullah F, Afridi AK, Rahim F, Ashfaq M, Khan S, Shabbier G, et al. Knowledge of diabetic complications in patients with diabetes mellitus. Journal of Ayub Medical College Abbottabad. 2015;27(2):360-3.

6. Jane K, Joanne M, Gallivan C: National Diabetes Education Program and the Role of Partnership in the Prevention and Management of Diabetes. Oxford: Oxford Scholarship, Online; 2011. Available from: http://www.sph.emory. edu/departments_centers/gh/documents/ Narayan_ DiabetesPH.pdf. (accessed 13 Feb 2013).

7. Maina WK, Njenga EW, Muchemi EW: Knowledge, attitude and practices related to diabetes among community members in four provinces in Kenya: a cross-sectional study. Pan Afr Med J 2010, 7(2):15-18. ISSN $1937-8688$.

8. Ulvi OS, Chaudhary RY, Ali T, Alvi RA, Khan MF, Khan M, Malik FA, et al: Investigating the awareness level about diabetes mellitus and associated factors in Tarlai (Rural Islamabad). J Pak Med Assoc 2009, 59:798-801.

9. Muninarayana C, Hiremath G, Krishna I, Anil NS: Prevalence and awareness regarding diabetes mellitus in rural Tamaka, Kolar. Int J Diabetes DevCtries 2010, 30(1):18-21.

10. Al Shafaee M, Al-Shukaili S, Rizvi S, Al Farsi Y, Khan M, Ganguly S, Afifi M, Al Adawi S: Knowledge and perceptions of diabetes in a semi-urban Omani population. BMC Public Health 2008, 8(1):249.

11. Danquah I, Bedu-Addo G, Terpe K-J, Micah F, Amoako Y, Awuku Y, Dietz E, van der Giet M, Spranger J, Mockenhaupt F: Diabetes mellitus type 2 in urban Ghana: characteristics and associated factors. BMC Public Health 2012, 12(1):210.

12. Unadike BC, Chineye S: Knowledge, awareness, and impact of diabetes among adolescents in Uyo, Nigeria. African Journal of Diabetes Medicine 2009, 3:12-14.

13. Mohieldein AH, Al Zohairy MA, Hasan M: Awareness of diabetes mellitus among Saudi non-diabetic population in Al-Qassim region, Saudi Arabia. J Diabetes Endocrinol 2011, 2:14-19.

14. Faeh D, William J, Tappy L, Ravussin E, Bovet P: Prevalence, awareness and control of diabetes in the Seychelles and relationship with excess body weight. BMC Public Health 2007, 7(1):163.

15. Foma MA, Saidu Y, Omoleke SA, Jafali J. Awareness of diabetes mellitus among diabetic patients in the Gambia: a strong case for health education and promotion. BMC Public Health 2013; 13:1124-1131

16. Prasad S. Type 2 diabetes: patient's knowledge on diabetes, its medications and complications at outpatient pharmacy, Colonial War Memorial hospital. Pharmacy Program, Fiji National University, College of medicine, nursing and health sciences, Suva, September, 2014.

17. Kamel M, Badawy YA, El-Zeiny NA, Merdan IA. Sociodemographic determinants of management behaviour of diabetic patients Part II. Diabetics' knowledge of the disease and their management behaviour. Eastern Mediterranean Health J. 1999; 5: 974- 983.

18. Caliskan D, Ozdemir O, Ocaktan E, Idil A. Evaluation of awareness of diabetes mellitus and associated factors in four health center areas. Patient Educ. Couns. 2006; 62: 142-147.

19. Powell CK, Hill EG, Clancy DE. The Relationship between health literacy and diabetes knowledge and readiness to take health actions. Diab. Educ. 2007; 33: 144-151.

20. Al Shafaee M A, Al-Shukaili S, Rizvi S G A, Al Farsi Y, Khan MA, Ganguly SS, Afifi M, Al Adawi S (2008). Knowledge and perceptions of diabetes in a semi-urban Omani population. BMC public Health. 2008; 8: 249. 
21. Mohieldein AH, Alzohairy MA, Hasan M. Awareness of diabetes mellitus among Saudi non-diabetic population in Al-Qassim region, Saudi Arabia. Journal of Diabetes and Endocrinology 2011; 2(2): 14-19.

22. Grandy S, Chapman RH, Fox KM. Quality of life and depression of people living with type 2 diabetes mellitus and those at low and high risk for type 2 diabetes: findings from the Study to Help Improve Early evaluation and management of risk factors leading to Diabetes (SHIELD). Int. J. Clin. Pract. 2008; 62: 562-68.

23. Sabra AA, Taha AZ, Al-Zubier AG, Al-Kurashi NY. Misconceptions about diabetes mellitus among adult male attendees of primary health care centres. SA. Fam. Pract. 2011; 52(4): 344-349.

24. Al-Daghri NM, Al-Attas OS, Al-Rubeaan K, Mohieldin M, Al-Katari M, Jones A F, Kumar S. Serum leptin and its relation to anthropometric measures of obesity in pre-diabetic Saudis. Cardiovasc. Diabetol. 2007; 6: 18.

25. Al-Attas OS, Al-Daghri NM, Al-Rubeaan K, da Silva NF, Sabico SL, Kumar S, McTernan PG, Harte AL. Changes in endotoxin levels in T2DM subjects on anti-diabetic therapies. Cardiovasc. Diabetol. 2009; 8: 20.

26. Al-Nozha MM, Al-Matouq MA, Al-Mazrou YY, et al. Diabetes in Saudi Arabia. Saudi Med J 2004; 25(11): 1603-10

27. Aljoudi AS, Taha AZA. Knowledge of diabetes risk factors and preventive measures among attendees of a primary care center in eastern Saudi Arabia. Ann. Saudi Med. 2009; 29: 15-19.

28. Stewart J, Brown K, Kendrick D, Dyas J. Understanding of blood pressure by people with type 2 diabetes: A primary care focus group study. Br. J. Gen. Pract. 2005; 55: 298-304.

29. Ulvi OS, Chaudhary RY, Ali T, Alvi R A, Khan M F A, Khan M, et al. Investigating the awareness level about Diabetes Mellitus and associated factors in Tarlai (Rural Islamabad). J. Pak. Med. Assoc. 2009; 59: 798-801.

30. Murugesan N, Snehalatha C, shobhana R, Roglic, G, Ramachandran A. Awareness about diabetes and its complications in the general and diabetic population in a city in southern India. Diab. Res. Clin. Pract. 2007; 77: 433-437.

31. Yun LS, Hassan Y, Aziz NA, Awaisu A, Ghazali R.. A comparison of knowledge of diabetes mellitus between patients with diabetes and healthy adults: a survey from north Malaysia. Patient Educ. Counsel. 2007; 69: 4754.

32. Al Rubeaan K. Diabetes education. Report on the Regional consultation on diabetes Prevention and control. Teheran, Islamic Republic of Iran. 2-5 February, 2003.

33. Oparah AC, Arigbe-Osula EM. Evaluation of Community Pharmacists' Involvement in Primary Health Care. Trop. J. Pharm. Res. 2002; 1: 67-74. 